\title{
Absence of TGFBR2 mutations in patients with spontaneous spinal CSF leaks and intracranial hypotension
}

\author{
Wouter I. Schievink • Ora K. Gordon • \\ James C. Hyland · Leena Ala-Kokko
}

Received: 27 December 2007/Revised: 14 January 2008/Accepted: 16 January 2008/Published online: 9 February 2008

(C) Springer-Verlag 2008

\begin{abstract}
A heritable connective-tissue-disorder often is suspected in patients with spontaneous spinal CSF leaks and intracranial hypotension, but the nature of the disorder remains unknown in most patients. The aim of this study was to assess the gene encoding TGF- $\beta$ receptor-2 (TGFBR2) as a candidate gene for spinal CSF leaks. We searched the $T G F B R 2$ gene for mutations in eight patients with spontaneous spinal CSF leaks who also had other features associated with $T G F B R 2$ mutations, i.e., skeletal features of Marfan syndrome, arterial tortuosity, and(or) thoracic aortic aneurysm. The mean age of these 7 women and 1 man was 38 years (range 14-60 years). We detected no TGFBR2 mutations and conclude that TGFBR2 mutations are not a major factor in spontaneous spinal CSF leaks.
\end{abstract}

Keywords CSF leak · Intracranial hypotension . Loeys-Dietz syndrome $\cdot$ Marfan syndrome

\section{Introduction}

Spontaneous intracranial hypotension is an important cause of new-onset headaches in young and middle-aged

W. I. Schievink $(\bowtie)$

Department of Neurosurgery, The Maxine Dunitz Neurosurgical Institute, Cedars-Sinai Medical Center, 8631 West Third Street, Suite 800E, Los Angeles, CA 90048, USA

e-mail: schievinkw@cshs.org

O. K. Gordon

Department of Medical Genetics, Cedars-Sinai Medical Center, Los Angeles, CA, USA

J. C. Hyland · L. Ala-Kokko

Connective Tissue Gene Tests, Allentown, PA, USA individuals [1]. The headache is typically orthostatic in character and numerous additional symptoms have been reported [1]. Spontaneous intracranial hypotension is caused by a spontaneous spinal cerebrospinal fluid (CSF) leak [1]. The underlying pathological substrate of such CSF leaks is varied, ranging from small dural rents and tears to complex fragile meningeal diverticula (arachnoid cysts) or absence of the dura normally enveloping the spinal nerve roots [1]. A history of a more or less trivial event precipitating the onset of symptoms can be elicited in about onethird of patients [2] while a heritable connective-tissue disorder is suspected on the basis of physical examination alone, e.g., isolated joint hypermobility, in up to two-thirds of patients with spontaneous intracranial hypotension [3]. The association between spontaneous intracranial hypotension and heritable connective-tissue disorders has been recognized since the mid-1990s [4-6], but well-characterized disorders, such as Marfan syndrome, Ehlers-Danlos syndrome type II, or autosomal dominant polycystic kidney disease, are found in only a small minority of patients $(<5 \%)[3,7]$. Isolated skeletal features of Marfan syndrome (i.e., without the major ocular or cardiovascular manifestations) are more common and are found in $10-20 \%$ of patients with spontaneous intracranial hypotension $[3,8$, 9]. We have shown that these patients do not harbor mutations in the fibrillin-1 gene ( $F B N 1)$, the gene responsible for classic Marfan syndrome. However, abnormalities of fibrillin-1 containing microfibrils have been demonstrated in these patients [8, 9]. Fibrillin-1 is a large glycoprotein containing transforming growth factor beta (TGF- $\beta$ ) and epidermal growth factor like domains [10]. Dysregulation of TGF- $\beta$ activation has been implicated in the pathogenesis of Marfan syndrome [10]. Recently, mutations in the gene encoding TGF- $\beta$ receptor-2 (TGFBR2) have been reported in patients who have the 
skeletal and cardiovascular, but lack the major ocular manifestations of Marfan syndrome [11-13]. This has been designated Marfan syndrome 2 [11-13]. Mutations in TGFBR2 also have been reported in patients with systemic arterial tortuosity commonly associated with arterial aneurysms/dissections and, less frequently, with hypertelorism, cleft palate, and bifid uvula (Loeys-Dietz syndrome) [14-17]. Therefore, we screened a group of patients with spontaneous intracranial hypotension, who also had skeletal features of Marfan syndrome, arterial tortuosity, and(or) thoracic aortic aneurysm for $T G F B R 2$ mutations.

\section{Methods}

We investigated eight patients with spontaneous spinal CSF leaks and intracranial hypotension who had isolated skeletal features of Marfan syndrome on physical examination, cervical artery tortuosity on MRA, and(or) thoracic aortic aneurysmal disease on echocardiography. All radiographic studies were reviewed by at least one boardcertified neuroradiologist. The study was approved by our medical center's Institutional Review Board.
All seven coding exons of the TGFBR2 gene coding for TGFBR2 were amplified by polymerase chain reaction (PCR). The amplified products were then sequenced using ABI 3730 sequencers and analyzed for sequence variations. The significance of the variations was determined by comparison with wild type sequences, previously reported mutations, and correlation with TGFBR2 protein structure.

\section{Results}

The mean age of the 7 women and 1 man at the time of onset of symptoms was 38 years (range, 14-60 years). Clinical and radiographic characteristics of the patient population are shown in Table 1. Three patients had minor isolated skeletal features of Marfan syndrome, three patients had cervical artery tortuosity, one patient had both the skeletal features and arterial tortuosity, and one patient had the skeletal features and a thoracic aortic aneurysm.

The minor skeletal features of Marfan syndrome consisted of tall stature, joint hypermobility and arachnodactyly (i.e., presence of thumb and wrist signs), and(or) high arched palate. Major skeletal manifestations,

Table 1 Characteristics of eight patients with spontaneous spinal cerebrospinal fluid leaks investigated for TGFBR2 mutations

\begin{tabular}{|c|c|c|c|c|c|}
\hline & Age, sex & $\begin{array}{l}\text { Site of CSF } \\
\text { leak }\end{array}$ & $\begin{array}{l}\text { Skeletal } \\
\text { features }\end{array}$ & $\begin{array}{l}\text { Cardiovascular } \\
\text { features }\end{array}$ & $\begin{array}{l}\text { Family } \\
\text { history }\end{array}$ \\
\hline 1. & $14, \mathrm{~F}$ & Thoracic & $\begin{array}{l}\text { Height } 172 \mathrm{~cm} \text { (95th perc.) } \\
\text { High arched palate } \\
\text { Joint hypermobility } \\
\text { Arachnodactyly }\end{array}$ & Normal & Father with joint hypermobility \\
\hline 2. & $22, \mathrm{~F}$ & $\begin{array}{r}\text { Thoracic (multiple } \\
\text { arachnoid cysts) }\end{array}$ & $\begin{array}{l}\text { Height } 183 \mathrm{~cm} \text { ( }>95 \text { th perc.) } \\
\text { Joint hypermobility } \\
\text { Arachnodactyly }\end{array}$ & Normal & $\begin{array}{l}\text { Brother with intracranial } \\
\text { arachnoid cyst }\end{array}$ \\
\hline 3. & $42, \mathrm{~F}$ & Cervical and thoracic & $\begin{array}{l}\text { Height } 173 \mathrm{~cm} \text { (95th perc.) } \\
\text { High arched palate } \\
\text { Joint Hypermobility }\end{array}$ & Normal & $\begin{array}{l}\text { Son with tall stature }(191 \mathrm{~cm}) \\
\text { and pectus excavatum } \\
\text { surgery }\end{array}$ \\
\hline 4. & $60, \mathrm{~F}$ & $\begin{array}{l}\text { Cervical, thoracic and } \\
\text { lumbosacral (multiple } \\
\text { arachnoid cysts) }\end{array}$ & $\begin{array}{l}\text { Height } 173 \mathrm{~cm} \text { (95th perc.) } \\
\text { Joint hypermobility } \\
\text { Arachnodactyly }\end{array}$ & $\begin{array}{l}\text { Cervical artery } \\
\text { tortuosity }\end{array}$ & $\begin{array}{l}\text { Multiple family members with } \\
\text { tall stature (up to } 198 \mathrm{~cm} \text { ) }\end{array}$ \\
\hline 5. & $39, \mathrm{~F}$ & Cervical and thoracic & Normal & $\begin{array}{l}\text { Cervical artery } \\
\text { tortuosity }\end{array}$ & $\begin{array}{l}\text { Cerebral aneurysm in two and } \\
\text { aortic aneurysm in two first- } \\
\text { or second-degree relatives }\end{array}$ \\
\hline 6. & $45, \mathrm{M}$ & Thoracic & Normal & $\begin{array}{l}\text { Cervical artery } \\
\text { tortuosity }\end{array}$ & Normal \\
\hline 7. & $36, \mathrm{~F}$ & $\begin{array}{r}\text { Thoracic (multiple } \\
\text { arachnoid cysts) }\end{array}$ & Normal & $\begin{array}{l}\text { Cervical artery } \\
\text { tortuosity }\end{array}$ & Normal \\
\hline 8. & $46, \mathrm{~F}$ & $\begin{array}{l}\text { Thoracic (multiple } \\
\text { arachnoid cysts) }\end{array}$ & $\begin{array}{l}\text { High-arched palate } \\
\text { Joint hypermobility } \\
\text { Arachnodactyly }\end{array}$ & $\begin{array}{l}\text { Thoracic aortic } \\
\text { aneurysm }\end{array}$ & Normal \\
\hline
\end{tabular}




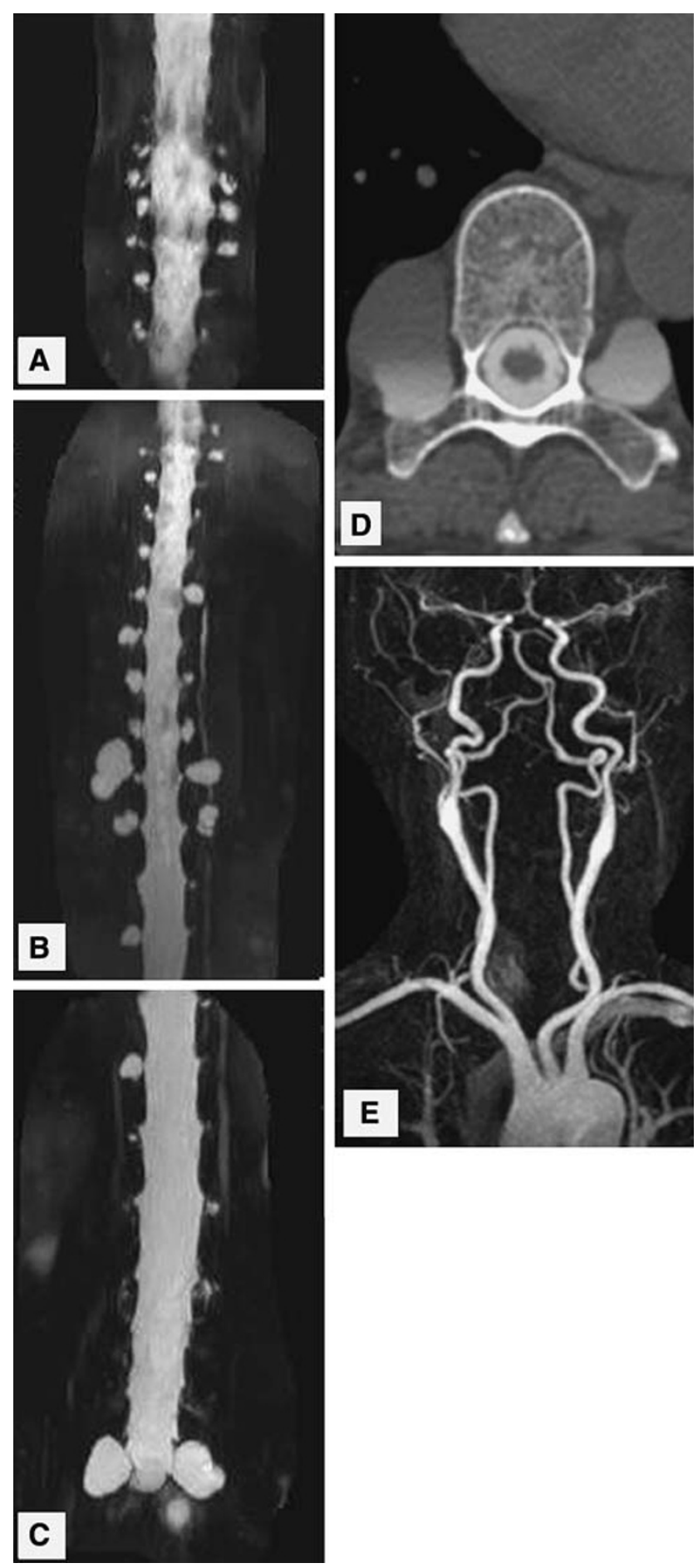

Fig. 1 Imaging results for patient 4 (see Table 1). MR-myelography of the cervical (a), thoracic (b), and lumbosacral (c) spine showing numerous spinal meningeal diverticula. Post myelography CT showing large bilateral thoracic meningeal diverticula (d). MRangiography showing tortuosity of both extracranial internal carotid arteries and the intracranial vertebrobasilar circulation (e)

e.g., pectus deformity or dolichostenomelia, were not present. Detailed ocular examination was performed in all five of these patients and showed moderate myopia (-4) in one patient and postoperative changes of cataract surgeries in one patient who had developed cataracts at age 44, but there was no evidence for ectopia lentis. Echocardiography was performed in four of these patients and showed a $4.3 \mathrm{~cm}$ thoracic aortic aneurysm in one patient, which was confirmed by CT scanning.

Arterial tortuosity affected the carotid and vertebral arteries. There was no evidence for dissection or aneurysm formation of the cervical or cerebral arteries in any of these patients. None of the patients had a personal or family history of spontaneous arterial dissection. One patient had a strong family history of both cerebral and aortic aneurysms. None of the patients had any of the facial characteristics of Loeys-Dietz syndrome.

Spinal imaging revealed findings typical of spontaneous intracranial hypotension with varying degrees of spinal CSF leaks and meningeal diverticula in seven of eight patients. The patient with both the minor skeletal findings of Marfan syndrome and cervical artery tortuosity, however, had an unusually large number of large meningeal diverticula measuring up to $3.5 \mathrm{~cm}$ in the thoracic spine (Fig. 1).

DNA sequencing of the TGFBR2 gene revealed no detectable mutations.

\section{Discussion}

No mutations in the TGFBR2 gene were detected in this group of patients with spontaneous intracranial hypotension. The TGFBR2 gene was a reasonable candidate gene for this group of patients with spontaneous intracranial hypotension, because patients also had the skeletal features of Marfan syndrome, arterial tortuosity, and(or) thoracic aortic aneurysmal disease, features that are found in patients with TGFBR2 mutations [10-17]. Spinal dural ectasia, a major manifestation of classical Marfan syndrome [18, 19], also has been reported in patients with $T G F B R 2$ mutations. In fact, dural ectasia was identified in the first reported patient with a TGFBR2 mutation [11].

The association of spontaneous intracranial hypotension with isolated skeletal features of Marfan syndrome was first reported in a 24-year-old woman with a CSF leak originating from a thoracic meningeal diverticulum [4]. Since, it has been shown that this association is found in about $10-20 \%$ of patients with spontaneous intracranial hypotension $[3,8,9]$ and that these patients are younger and more often harbor multiple spinal meningeal diverticula compared to other patients with spontaneous intracranial hypotension [8, 9]. Abnormalities of microfibrils have been demonstrated in these patients by different techniques $[8$, 9]. Mutations in FBN1 [8,9] and now TGFBR2 have been excluded in this patient population. Also, no FBN1 
mutations were detected in a group of patients with spontaneous intracranial hypotension who did not have any evidence for a generalized connective-tissue disorder [20].

Because of the protean clinical manifestations of spontaneous intracranial hypotension, imaging of the cervical vasculature is frequently performed in these patients. Therefore, we were able to demonstrate the presence of arterial tortuosity in some of our patients with spontaneous intracranial hypotension. Cervical arterial tortuosity has been associated with an increased risk of spontaneous cervical artery dissection and patients with both spontaneous intracranial hypotension and spontaneous cervical artery dissection have been reported [3, 7]. Systemic arterial tortuosity, including the carotid and vertebral arteries, is the hallmark of Loeys-Dietz syndrome [13-17]. This syndrome is caused by mutations in the TGFBR2 or, less frequently, in the TGFBRl gene and is associated with spontaneous arterial dissections and aneurysm formation as well as craniofacial anomalies such as bifid uvula and hypertelorism [13-17]. None of the patients in our study had such craniofacial anomalies.

\section{Conclusion}

Mutations in TGFBR2 are not a major factor in the etiology of spontaneous spinal CSF leaks and intracranial hypotension.

\section{References}

1. Schievink WI (2006) Spontaneous spinal cerebrospinal fluid leaks and intracranial hypotension. JAMA 295:2286-2296

2. Schievink WI, Louy C (2007) Precipitating factors of spontaneous spinal CSF leaks and intracranial hypotension. Neurology 69:700-702

3. Schievink WI, Gordon OK, Tourje J (2004) Connective tissue disorders with spontaneous spinal cerebrospinal fluid leaks and intracranial hypotension: a prospective study. Neurosurgery 54:65-70

4. Schievink WI, Reimer R, Folger WN (1994) Surgical treatment of spontaneous intracranial hypotension associated with a spinal arachnoid diverticulum. Case report. J Neurosurg 80:736-739
5. Davenport RJ, Chataway SJ, Warlow CP (1995) Spontaneous intracranial hypotension from a CSF leak in a patient with Marfan's syndrome. J Neurol Neurosurg Psychiatry 59:516-519

6. Schievink WI, Torres VE (1997) Spinal meningeal diverticula in autosomal dominant polycystic kidney disease. Lancet 349:12231224

7. Mokri B, Maher CO, Sencakova D (2002) Spontaneous CSF leaks: underlying disorder of connective tissue. Neurology 58:814-816

8. Schievink WI, Schrijver I, Meyer FB, Francke U (1998) A syndrome of spontaneous spinal cerebrospinal fluid leaks and skeletal features of Marfan syndrome (abstract). Ann Neurol 44:458

9. Schrijver I, Schievink WI, Godfrey M, Meyer FB, Francke U (2002) Spontaneous spinal cerebrospinal fluid leaks and minor skeletal features of Marfan syndrome: a microfibrillopathy. J Neurosurg 96:483-489

10. Ramirez F, Sakai LY, Rifkin DB, Dietz HC (2007) Extracellular microfibrils in development and disease. Cell Mol Life Sci 64:2437-2446

11. Mizuguchi T, Collod-Beroud G, Akiyama T et al (2004) Heterozygous TGFBR2 mutations in Marfan syndrome. Nat Genet 36:855-860

12. Disabella E, Grasso M, Marziliano N et al (2006) Two novel and one known mutation of the TGFBR2 gene in Marfan syndrome not associated with FBN1 gene defects. Eur J Hum Genet 14:34-38

13. Singh KK, Rommel K, Mishra A et al (2006) TGFBR1 and TGFBR2 mutations in patients with features of Marfan syndrome and Loeys-Dietz syndrome. Hum Mutat 27:770-777

14. Loeys BL, Chen J, Neptune ER et al (2005) A syndrome of altered cardiovascular, craniofacial, neurocognitive and skeletal development caused by mutations in TGFBR1 or TGFBR2. Nat Genet 37:275-281

15. Pannu H, Fadulu VT, Chang J et al (2005) Mutations in transforming growth factor-beta receptor type II cause familial thoracic aortic aneurysms and dissections. Circulation 112:513-520

16. Loeys BL, Schwarze U, Holm T et al (2006) Aneurysm syndromes caused by mutations in the TGF-beta receptor. $\mathrm{N}$ Engl J Med 355:788-798

17. Johnson PT, Chen JK, Loeys BL, Dietz HC, Fishman EK (2007) Loeys-Dietz syndrome: MDCT angiography findings. AJR Am J Roentgenol 189: W29-35

18. Pyeritz RE, Fishman EK, Bernhardt BA, Siegelman SS (1988) Dural ectasia is a common feature of the Marfan syndrome. Am J Hum Genet 43:726-732

19. Fattori R, Nienaber CA, Descovich B et al (1999) Importance of dural ectasia in phenotypic assessment of Marfan's syndrome. Lancet 354:910-913

20. Chung SJ, Ki CS, Lee MC, Lee JH (2007) Fibrillin-1 gene analysis of Korean patients with spontaneous CSF hypovolemia. Headache 47:111-115 